\title{
Effectiveness of Selected Soil Conservation Practices on Soil Erosion Control and Crop Yields in the Usambara Mountains, Tanzania
}

\author{
S. B. Mwango ${ }^{1 *}$, B. M. Msanya ${ }^{1}$, P. W. Mtakwa ${ }^{1}$, D. N. Kimaro ${ }^{2}$, J. Deckers ${ }^{3}$, \\ J. Poesen ${ }^{3}$, I. Massawe ${ }^{1}$ and J. Samwel ${ }^{1}$ \\ ${ }^{1}$ Department of Soil Science, Sokoine University of Agriculture, P.O.Box 3008 Chuo Kikuu, Morogoro, \\ Tanzania. \\ ${ }^{2}$ Department of Agricultural Engineering and Land Planning, Sokoine University of Agriculture, \\ P.O.Box 3003 Chuo Kikuu, Morogoro, Tanzania. \\ ${ }^{3}$ Department of Earth and Environmental Sciences, KU Leuven, Celestijnenlaan 200 E, \\ B-3001 Heverlee, Belgium.
}

Authors' contributions

This work was carried out in collaboration between all authors. Author SBM designed the study, wrote

the protocol, conducted field work, performed statistical analysis, and wrote the first draft of the manuscript. Author BMM designed the study, conducted field work, managed the literature searches and edited drafts. Author PWM designed the study, conducted field work and edited drafts. Authors DNK, JD and JP designed the study and edited drafts. Authors IM and JS conducted field work. All authors read and approved the final manuscript.

Article Information

DOI: $10.9734 / J A E R I / 2015 / 13636$ Editor(s):

(1) Anonymous.

(2) Edward Wilczewski, Faculty of Agriculture, University of Technology and Life Sciences in Bydgoszcz, Poland. Reviewers:

(1) Yahya Isa Farhan, Department of Geography, Faculty of Arts, The University of Jordan, Amman, Jordan. (2) Eric Takyi Atakora, Dept.of Agricultural Engineering, Kwame Nkrumah University of Science and Technology, Ghana. (3) Anonymous, Technical University Of Madrid, Spain (4) Anonymous, Kanpur University, U.P. India. (5) Anonymous, University of Kalyani, India.

Complete Peer review History: http://www.sciencedomain.org/review-history.php?iid=872\&id=37\&aid=7330

Original Research Article

Received $26^{\text {th }}$ August 2014

Accepted 18 ${ }^{\text {th }}$ October 2014 Published $16^{\text {th }}$ December 2014

\section{ABSTRACT}

Indigenous soil conservation measures such as miraba have been widely used in Usambara Mountains for controlling soil erosion but with little success. On-farm runoff experiments were set from 2011-2014 on Acrisols in Majulai and Migambo villages with contrasting agro-ecological 
conditions in the Usambara Mountains, Tanzania. The aim was to investigate the effectiveness of miraba and miraba with various mulching materials in reducing runoff, soil and nutrient losses and improving productivity of maize (Zea mays) and beans (Phaseolus vulgaris). Results show that mean annual runoff coefficients $\left(\mathrm{mm} \mathrm{mm}^{-1}\right)$ ranged from 0.72 for cropland with no soil conservation measure (control) to 0.15 for cropland with miraba and Tithonia (Tithonia diversifolia) mulching in Majulai village and respectively from 0.68 to 0.13 in Migambo village. Soil loss was significantly $(P$ $=.05$ ) higher under control than under miraba with either Tughutu (Vernonia myriantha) or Tithonia mulching e. g. 184 vs. 20 in Majulai and 124 vs. $8 \mathrm{Mg} \mathrm{ha}^{-1}$ year $^{-1}$ in Migambo village in 2012. The $P$ factors were significantly $(P=.05)$ higher under miraba sole than under miraba with mulching in Majulai village (0.18 vs. 0.11$)$ and in Migambo village (0.10 vs. 0.05$)$. The annual nutrient losses in $\mathrm{kg} \mathrm{ha}^{-1} \mathrm{yr}^{-1}$ were significantly $(P=.05)$ higher under control than under miraba with mulching 367 vs. 37 total $\mathrm{N}, 0.8$ vs. $0.1 \mathrm{P}$ and 14 vs. $4 \mathrm{~K}$ for Majulai village; 474 vs. 26 total $\mathrm{N}, 0.7$ vs. $0.1 \mathrm{P}$ and 20 vs. $1.2 \mathrm{~K}$ for Migambo village in 2012. Maize and bean yields were significantly $(P=.05)$ higher under miraba with Tughutu mulching than under control (e.g. 2.0 vs. $0.7 \mathrm{Mg} \mathrm{ha}^{-1}$ for maize in Majulai in 2012). Thus miraba with Tughutu mulching is more effective in improving crop yields than miraba with Tithonia and miraba sole.

Keywords: Runoff experiments; indigenous SWC; soil and nutrient losses; miraba, RUSLE; maize; beans.

\section{INTRODUCTION}

Soil erosion has been reported as a serious problem facing agricultural production all over the world [1-5]. Soil erosion by water is a major factor causing land degradation in the Usambara highlands of Tanzania and severely affects soil functions resulting in low crop productivity $[6,7]$. Soil erosion by water is defined as the detachment and displacement of soil particles by water, resulting in the development of rills and gullies [8]. To overcome the problem of soil deterioration, the Usambara farmers have developed local soil and water conservation (SWC) measures such as miraba (rectangular grass bound strips that do not necessarily follow contour lines [9]), micro-ridges and stone bunds as an integral part of their farming systems $[7,9,10]$. Most of the introduced measures have often been rejected or minimally adopted because such measures e.g. bench and Fanya Juu terraces (hillside ditches made by throwing excavated soil on the upslope of the ditch, built along the contour lines at appropriate intervals depending on slope) were expensive in terms of labour and money, while also their promoters paid little attention on indigenous practices.

Miraba are widely practised by farmers in the Usambara Mountains. Miraba as a SWC measure is traditionally characterized by a wide spacing of grass strips across the slope and usually the spacing depends on the size of farm plots. For decades these SWC technologies were never a subject of scientific writing to allow improvements be made to effectively address problems of soil degradation and low crop productivity [10]. On the other hand, farmers have not been able to adjust these indigenous SWC techniques to rapidly changing farming systems and increasing intensity of land use $[11,10]$.

On steep slopes like in Usambara Mountains, bench terraces are highly recommended as the most effective soil and water conservation measure in cropland $[12,7,10,13)$. However, due to low adoption rates in Usambara Mountains, the solution would be to improve and use indigenous SWC technologies such as miraba for sustained agricultural productivity in the area.

In the Usambara Mountains miraba are established by using either Napier or Guatemala grass. Grass strips forming miraba serve as barriers which capture soil particles that have been detached and transported with runoff from the cultivated land. Napier grass is mostly preferred because it is also used as forage for stall feeding, while Guatemala grass is appreciated for its drought resistance and to some extent is also used as for age for stall feeding.

Studies on effectiveness of some SWC technologies such as bench terraces, Fanya Juu terraces, grass strips $[7,14]$ and miraba $[15,16]$ on soil erosion control and agricultural productivity have recently been carried out in Western Usambara Mountains. However, the 
contribution of indigenous SWC technologies including miraba mostly practised in the study area have not fully been investigated for sustained agricultural productivity $[10,15]$. Moreover, it has been reported that establishment of miraba is far cheaper than the construction of bench terraces. Therefore efforts towards improving this technique are warranted $[14,15,16]$.

Several erosion models are available to predict soil loss and to assess soil erosion risk [4,9]. However, RUSLE, the Revised Universal Soil Loss Equation [17] is widely used for estimating potential soil erosion by water especially at regional and national level because of its relative simplicity and robustness $[4,18,16]$. Likewise, this study applied RUSLE model to investigate the effectiveness of miraba and miraba with Tithonia (Tithonia diversifolia) and Tughutu (Vernonia myriantha) mulching materials in reducing runoff, soil and nutrient losses using maize and beans as test crops. Specifically, the study intended to: (i) quantify soil and nutrient losses under selected soil conservation practices (ii) determine rainfall-runoff responses under selected soil conservation practices (iii) select the best soil conservation practice using the Revised Universal Soil Loss Equation (RUSLE) and (iv) determine the influence of selected soil conservation practices on crop yield.

\section{MATERIAL AND METHODS}

\subsection{Description of the Study Sites}

The study was conducted in Migambo and Majulai villages which represent different agroecological zones in Western Usambara Mountains, Lushoto District, Tanzania (Fig. 1) located between longitudes $38^{\circ} 15^{\prime}$ to $38^{\circ} 24^{\prime} \mathrm{E}$ and latitudes $4^{\circ} 34^{\prime}$ to $4^{\circ} 48^{\prime} \mathrm{S}$. The area is highly dissected with steep slopes ranging from $20 \%$ to over $50 \%$ and altitude of about 1402 m.a.s.l.in Majulai and 1682 m.a.s.l. in Migambo village. Migambo is humid cold with mean annual air temperature of $12-17^{\circ} \mathrm{C}$ and annual precipitation is $800-2300 \mathrm{~mm}$ [16]. Majulai is dry and warm with mean annual air temperature between 16 and $21^{\circ} \mathrm{C}$ and annual precipitation of $500-1700$ $\mathrm{mm}[13,16]$. The monthly reference evapotranspiration (ETo) as estimated by the local climate estimator software (New_LocClim) [19] ranges from $100 \mathrm{~mm}$ to $145 \mathrm{~mm}$. Majulai and Migambo villages support a large population density of more than 120.4 persons $/ \mathrm{km}^{2}$ [20].
According to the World Reference Base (WRB) [21], the soil type in Majulai site classifies as Chromic Acrisol (Humic, Profondic, Clayic, Cutanic, Colluvic) whereas in Migambo site the soil is Haplic Acrisol (Humic, Profondic, Clayic, Colluvic). The main land uses include cultivation on slopes and in valleys, settlements on depressions, ridge summits and slopes and forest reserves on ridge summits and upper slopes. Vegetables such as carrots, onions, tomatoes, cabbages, and peas are grown as sole crops in valleys under rain fed or traditional irrigation. Beans are mainly grown during the long rainy season while maize is grown during the short rains. Round potatoes and fruits, namely peaches, plums, pears, avocado and banana are grown on ridge slopes under rain fed mixed farming. Round potatoes are also grown in valleys as sole crop or intercropped with maize.

\subsection{Miraba Establishment in Runoff Experiments}

Miraba were established by using Napier grass (Pennisetum purpureum) barriers in runoff experiments in April 2011 about nine months before data collection started. Napier grass barriers forming miraba were established by planting tillers in a single row at $10 \mathrm{~cm}$ spacing perpendicular to slope and were maintained to about $50 \mathrm{~cm}$ wide strips. In the current study Napier grass barriers across the slope were spaced $5 \mathrm{~m}$ apart to mimic the recommended maximum effective width of hand made bench terraces [12]. Along the slope the Napier grass barriers were set at $3 \mathrm{~m}$ apart. It has been documented that soil conservation measures such as Fanya Juu and stone bunds tend to progressively form bench terraces when they are at narrow spacing $[12,22]$. Moreover, the closer the grass strips are, the more effective they become [22]. Progressive bench terrace formation is also possible under miraba when adjusted to appropriate spacing of grass strips. Natural bench terrace formations as a result of miraba implementation are much less expensive compared to mechanical bench terrace construction. Bench terraces are highly recommended for use in Usambara Mountains $[23,6,7,10]$.

\subsection{Experimental Design}

Closed runoff plots of $22 \mathrm{mx} 3 \mathrm{~m}$ in a randomized complete block design (RCBD) were set along lower ridge slopes at $50 \%$ slope in Majulai and 
$45 \%$ slope in Migambo village respectively. The plots were enclosed by miraba and bounded by pieces of wood that protruded $15 \mathrm{~cm}$ above the soil surface to prevent inflow and outflow from the plot borders. The pieces of wood were connected to three collector drums (each 220 litres) with hinged lids. Maize (Zea mays) and beans (Phaseolus vulgaris) were planted inrotation as test crops in 2012 and 2013/14 rainy seasons. Maize was planted during short rains (vuli), while beans were planted during long rains (masika).The treatments included runoff plots (Fig. 2) with: (i) Miraba with maize or beans (MI) (ii) Miraba with Tithonia mulching and planted with maize or beans (MITH) (iii) Miraba with Tughutu mulching and planted with maize or beans (MITG) (iv) plots without SWC measure and planted with maize or beans (Control) (CO) (v) Bare plots $(B A)$, all replicated three times. Mulching materials were the leaves of the readily available shrubs in both villages namely Alizeti Pori (Tithonia diversifolia) and Tughutu (Vernonia myriantha). Tithonia has frequently been reported as a good green manure while also Tughutu is known to contain $\mathrm{N}, \mathrm{P}$ and $\mathrm{K}$ $[24,25,26]$. Samples were collected from each mulching material for determination of total $\mathrm{N}$, available $\mathrm{P}, \mathrm{K}^{+}, \mathrm{Mg}^{2+}, \mathrm{Ca}^{2+}$ and $\mathrm{Na}^{+}$.

\subsection{Rainfall Data Collection}

Daily rainfall was measured from $1^{\text {st }}$ January 2012 to $16^{\text {th }}$ February 2014 using standard rain gauges and tipping buckets with a CR10 data logger (Campbell Scientific, Logan UT) installed at the experimental sites in Migambo and Majulai villages.

\subsection{Runoff, Sediment and Nutrient Loss Determination}

Runoff and sediment was collected daily from $1^{\text {st }}$ January 2012 to $16^{\text {th }}$ February 2014 . Beans were grown during the long rains, weeds were left to grow in the field during off season, and maize was grown in short rains. Runoff volume was estimated by measuring the depth of water in $\mathrm{cm}$ in the collecting drums and then converted to volume of water in litres. Sediment load was estimated by sampling water in collecting drums after vigorously stirring the suspension.
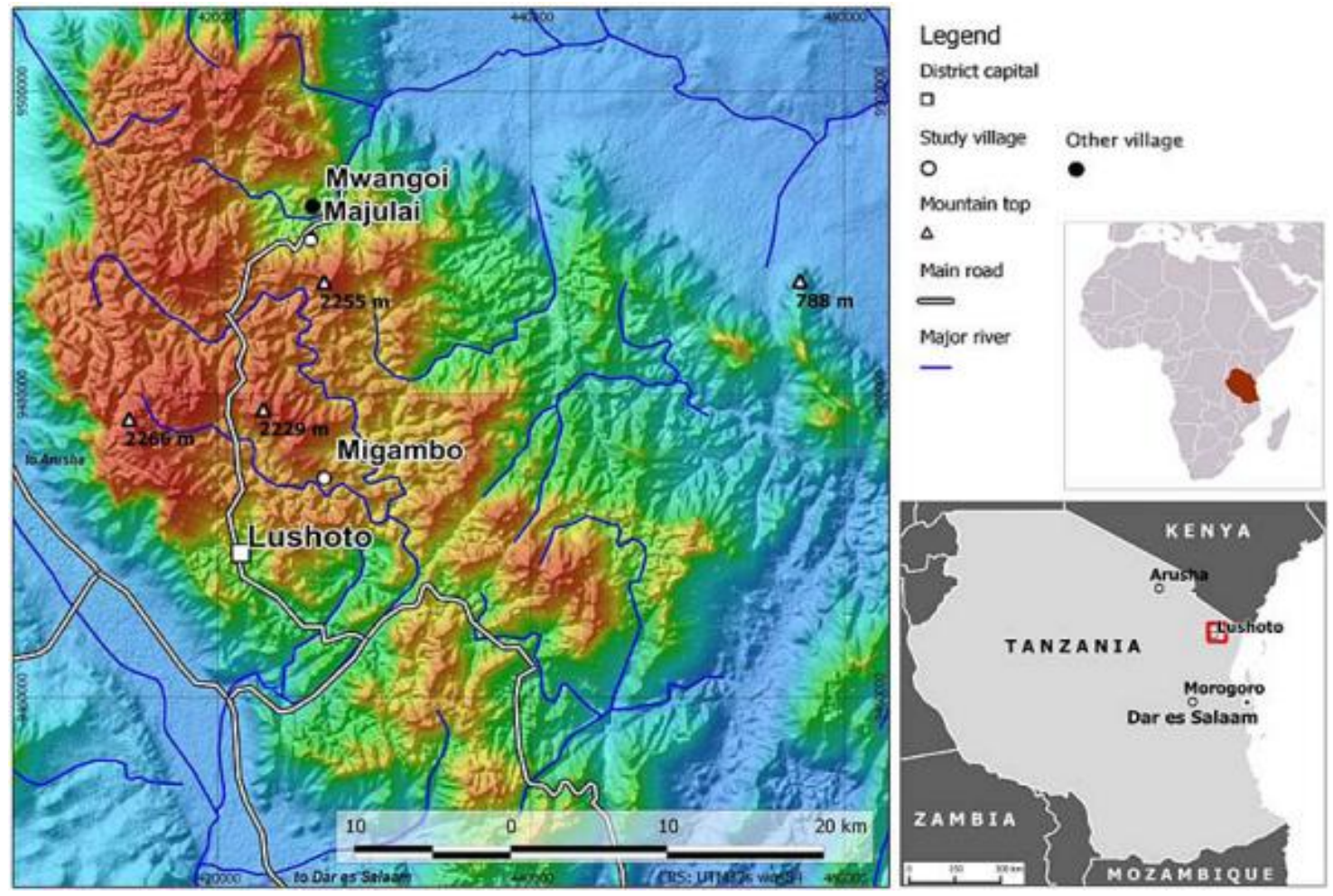

Fig. 1. Location map of Majulai and Migambo villages, Lushoto District, Tanzania. (Adapted from Msita, [16]) 

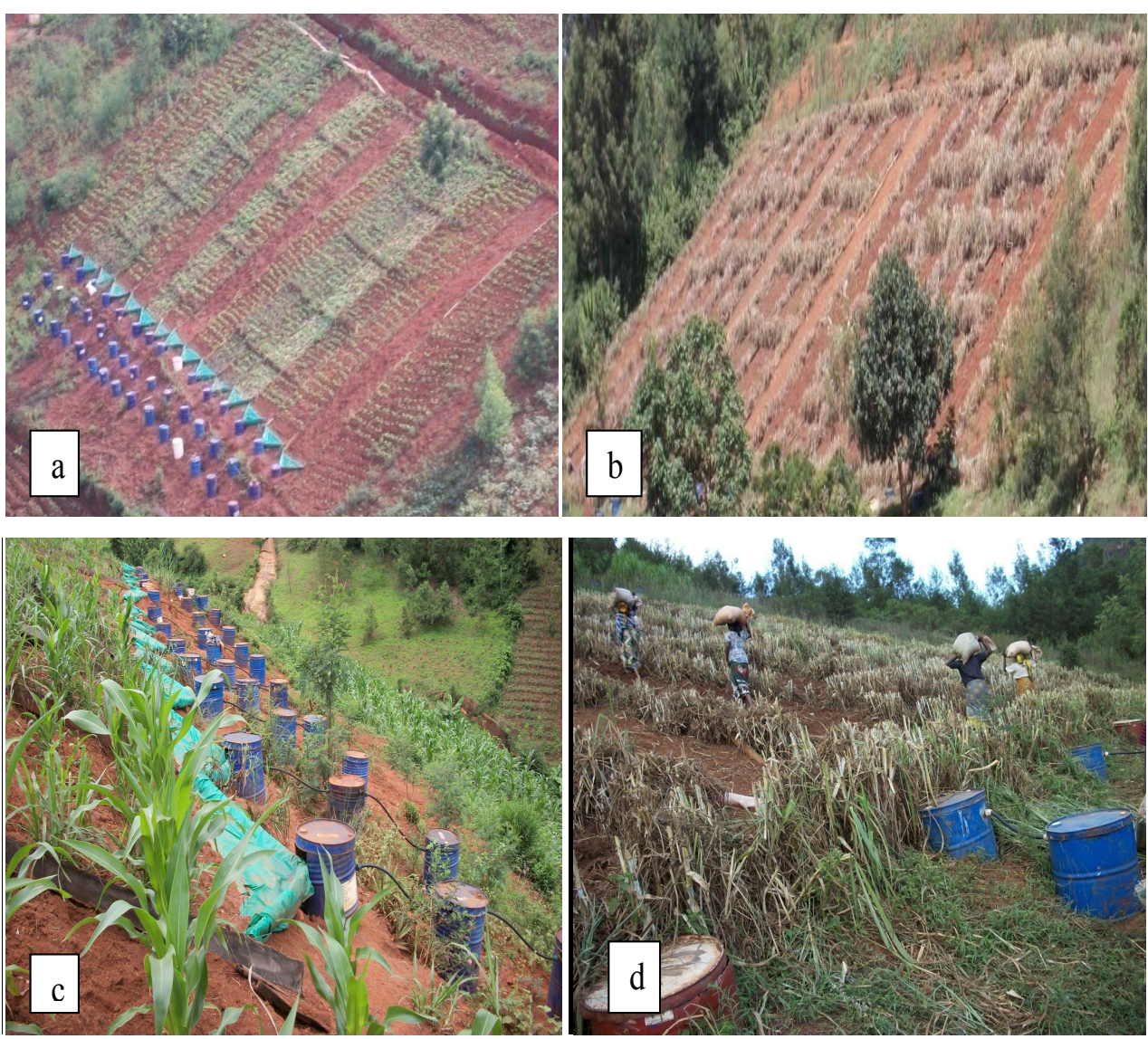

Fig. 2. Illustration of experimental plots a) Majulai plots layout b) Migambo plots layout c) Majulai plots with maize crop d) Migambo plots and application of farm yard manure

The water sampling was done by lowering a one litre plastic bottle from the water surface to the bottom of the drum, and samples of about $100 \mathrm{ml}$ were collected at the bottom, middle and upper part when runoff depth in the drum was above 25 $\mathrm{cm}$. Heavy sediments in the drums were scooped out, weighed and a $1 \mathrm{~kg}$ soil sample collected, oven dried for 24 hours at $105^{\circ} \mathrm{C}$ and weighed for dry soil loss calculation. The suspended sediment samples were filtered using Whatman No. 42 filter paper and dried for 24 hours at $105^{\circ} \mathrm{C}$ until constant weight was obtained [27] and the soil loss $\left(\mathrm{Mg} \mathrm{ha}^{-1} \mathrm{yr}^{-1}\right)$ was determined. Soil losses from heavy sediments and from suspended materials from each runoff event were added to compute total soil loss for the events. These losses were finally added to compute total soil loss per annum. The soil samples for nutrient loss determination were collected by decanting the suspended sediment in buckets.
In each runoff experimental site a soil profile was excavated and soil samples were collected from each horizon for pedological characterization. Undisturbed core soil samples were taken at 0-5 $\mathrm{cm}, 45-50 \mathrm{~cm}$ and $95-100 \mathrm{~cm}$ soil depth by Kopeck's core rings $\left(100 \mathrm{~cm}^{3}\right)$ for bulk density, gravimetric moisture and available moisture determinations. The soil was classified to Tier-2 according to the World Reference Base for Soil Resources WRB [21].

\subsection{Crop Yields}

Maize (Zea mays) PAN 67 variety and beans (Phaseolus vulgaris) Kilombero variety were planted in runoff plots during the 2012 and 2013/14 rain seasons with maize in the short rains (vuli) and beans in the long rains (masika) at the recommended spacing of $30 \mathrm{~cm}$ within rows and $75 \mathrm{~cm}$ between rows for maize and 25 $\mathrm{cm}$ within rows and $50 \mathrm{~cm}$ between rows for beans. Beans were always planted one month before the maize was harvested in Migambo and 
two weeks before harvesting maize in Majulai village. Farmyard manure with $1.7 \% \mathrm{~N}, 0.4 \% \mathrm{P}$ and $1.9 \% \mathrm{~K}$ was basal and spot applied at the rate of $3.6 \mathrm{Mg} \mathrm{ha}^{-1}$ air-dry weight, diammonium phosphate (DAP) 18: 46: 0 NPK ratio and Urea $46 \% \mathrm{~N}$ were applied at the rate of $80 \mathrm{~kg} \mathrm{ha}^{-1}$, but Urea was not applied for beans. At maturity maize and bean grains were harvested and dried to about $13 \%$ moisture content.

\subsection{Soil Analysis}

Soil analysis was done following Moberg's [28] Laboratory Manual. Organic carbon (OC) was measured using the dichromate oxidation method, total nitrogen (TN) by Kjeldahl method, available phosphorus (Bray-I), exchangeable bases $\left(\mathrm{Ca}^{2+}\right.$ and $\left.\mathrm{Mg}^{2+}\right)$ by atomic absorption spectrophotometer, exchangeable $\mathrm{Na}^{+}$and $\mathrm{K}^{+}$by flame photometer and $\mathrm{pH}$ water by normal laboratory $\mathrm{pH}$ meter.

\subsection{Determination of the RUSLE Factors}

The RUSLE equation expresses average annual soil loss $\mathrm{Mg} \mathrm{ha}^{-1}$ year $^{-1}$ caused by sheet and rill

erosion [17];

$$
A=R K L S C P \text {. }
$$

Where $A$ is the long term average soil loss (Mg $\mathrm{ha}^{-1}$ year $^{-1}$ ), $R$ is rainfall erosivity factor (MJ mm $\mathrm{ha}^{-1} \mathrm{~h}^{-1}$ year $\left.^{-1}\right), K$ is the soil erodibility factor (Mg ha $\left.\mathrm{MJ}^{-1} \mathrm{~mm}^{-1}\right), L S$ is dimensionless factor combining slope steepness $(S)$ and slope length $(L), \quad C$ and $P$ are dimensionless factors accounting respectively for crop cover and management and conservation practices. The equation developed by Vrieling et al. [29] was used to calculate Rfactor. Such that $R=50.7$

$$
M F I-1405
$$

Where MFI is the Modified Fournier Index

calculated from

$$
M F I=\sum_{n=1}^{\infty}\left(p^{2}\right) / \mathrm{P}
$$

Where $p$ is the average monthly rainfall $(\mathrm{mm})$ and $P$ is the average annual rainfall $(\mathrm{mm})$. In the absence of any cover crop or soil protection measure, as for the bare plot, $C$ and $P$ factors are equal to 1 . Thus $K$ factor was calculated from

$$
K=A_{\text {bare plot }} /(R L S)
$$

According to Mitchell and Bubenzer [30], LS = $\left[0.065+0.0456 \mathrm{~s}+0.006541 \mathrm{~s}^{2}\right] \mathrm{x}$

$$
(\mathrm{I} / 22)^{1 / 2}
$$

Where: s, is the slope gradient in $\% ; \mathrm{I}$, is the plot length in $\mathrm{m}$; constant $1 / 2$, is used where slope steepness is $\geq 5 \%$

The effectiveness of soil conservation practices on reducing soil loss was determined by the use of $C$ and $P$ factors when compared to the bare plots. The $C$ factor in the long rain season was a function of the bean crop cover; in the off season the $C$ factor was determined by weed cover, while in the short rains maize cover was considered. The $C$ factor was calculated as the ratio between the seasonal or annual soil losses of the control plot to the seasonal or annual soil losses of the bare plot. The $P$ factor was calculated as the ratio between the seasonal or annual soil losses under miraba plots to the seasonal or annual soil losses under control plots.

$C(C O$ plot $)=A(C O$ plot $) / A(B A$ plot $)$

$P(M l$ plot $)=A(M l$ plot $) / A(C O$ plot $)$

$P($ MITH plot $)=A(M I T H$ plot $) / A(C O$ plot $) \ldots . .$.

$P($ MITG plot $)=A($ MITG plot $) / A(C O$ plot $)$

Where: $A(C O$ plot $)$, is the soil loss $\left(\mathrm{Mg} \mathrm{ha}^{-1}\right.$ season $^{-1}$ or $\left.\mathrm{Mg} \mathrm{ha}^{-1} \mathrm{yr}^{-1}\right)$ under control plots; $A(B A$ plot), is the soil loss (Mg ha ${ }^{-1}$ season $^{-1}$ or $\mathrm{Mg}$ ha ${ }^{1} \mathrm{yr}^{-1}$ ) under control plots; A (MI, MITH and MITG plot), are respectively the soil loss $\left(\mathrm{Mg} \mathrm{ha}^{-1}\right.$ season $^{-1}$ or $\mathrm{Mg} \mathrm{ha}{ }^{-1} \mathrm{yr}^{-1}$ ) under miraba, miraba with Tithonia mulching and miraba with Tughutu mulching. The effectiveness of soil conservation practices on reducing soil loss was determined by the percent of $C$ and $P$ factors with reference to bare plots. The effectiveness of soil conservation practices on reducing nutrient losses was also calculated in percentages in respect of bare plots.

\subsection{Statistical Analysis}

Bartlett's test for homogeneity of variance was conducted to test data normality using GenStat software [31]. The relationships between daily rainfall and daily runoff were determined by 
Linear Regression Analysis with threshold runoff values obtained from the $X$-axis intercept. Analysis of Variance (ANOVA) in Gen Stat statistical software [31] was performed where Least Significant Difference $\left(\mathrm{LSD}_{0.05}\right)$ was used to detect mean differences between treatments.

\section{RESULTS AND DISCUSSION}

\subsection{Rainfall Erosivity between the Two Villages with Contrasting Climatic Conditions}

The annual and seasonal rainfalls recorded during the two consecutive years are presented in Table 1, while rainfall distribution in Fig. 3. It can be seen that, as the rainfall depth was higher in Majulai village than Migambo village in 2012, rainfall erosivity $R$ factor was also higher in Majulai, while in 2013 higher values of rainfall depth and $R$ factor were observed in Migambo village (Table 1).

\subsection{Soil loss in Relation to SWC Measures in the Two Villages with Contrasting Climatic Conditions}

From our results (Table 1), Majulai village had significantly $(P<.001)$ higher annual soil losses than Migambo in 2012, but in 2013 annual soil losses weresignificantly $(P<.001)$ higher in Migambo than in Majulai village. The difference in soil losses between the two villages can partly be attributed to the rainfall depth (Table 1), as it can clearly be seen that the higher the rainfall depth the higher the soil losses in the studied villages. Similar observations were reported by Kabanza et al. [32], where soil losses in Makonde plateau were much higher than in in land plains and rainfall depth was spotted as the main contributing factor. The relatively steeper slopes in Majulai than in Migambo could also explain the soil loss differences. This is supported by the work of Liu et al. [33] where slope gradients were found to be strong determinants of soil loss. On the other hand, soil losses differed significantly $(P<.001)$ between SWC measures in both villages. Soil losses followed the trend: bare plots $>$ cropl and with no SWC measures > cropl and with miraba sole > cropl and with miraba and Tithonia or Tughutu mulching. The reduced soil losses under miraba and miraba with mulches could be explained by the effect of grass barriers forming miraba that captured some soil sediments that were with runoff. This observation is also supported by Wanyama et al. [34] who reported grass strips to effectively trap more than $70 \%$ sediments under natural rainfall. Besides, miraba were progressively forming bench terraces such that the terrace height reached about $1 \mathrm{~m}$ in Migambo and $0.7 \mathrm{~m}$ in Majulai village after two years of experimentation. The terraces so formed reduced the slope steepness, thereby resulting reduced runoff velocity and increased rate of infiltration. This ultimately reduced runoff volume and sediment losses. Similarly, mulches also reduced runoff velocity, thereby increasing rate of infiltration and reducing runoff volume and sediment losses.Such observations were also reported by Bajracharya et al. and Tiwari et al. $[35,36]$ in Nepal where mulching was found to reduce annual soil loss by 60 to $90 \%$ in maizemustard cropping system as compared to conventional farmers' practices.

\subsection{Rainfall-Runoff Responses under Selected Soil Conservation Practices}

The slope of the regression line was used as a measure of the rainfall-runoff response. The rainfall-runoff response varied between the villages and between soil conservation measures (Fig. 4a). The differences can be explained by the influences of the studied soil conservation measures; bare plots had the highest annual runoff coefficient, while miraba with Tithonia and miraba with Tughutu mulching had the lowest (Table 2 \& Fig. 4). The rainfall threshold values to initiate runoff varied between the soil conservation measures and between the studied villages. These differences were also directly associated with the effects of soil conservation measures and the differences in climatic conditions between the villages (Fig. 3). The rainfall threshold values to initiate runoff follow the trend: miraba with Tithonia and miraba with Tughutu mulching > miraba sole $>$ cropl and with no SWC measures > bare land in both villages. Miraba with mulching had the highest rainfall threshold values i.e. $5.0 \mathrm{~mm}$ in Migambo village and lowest values under bare land i.e. $3.4 \mathrm{~mm}$ in Majulai village. The observed rainfall threshold values are very low implying that the soils of Usambara Mountains are very sensitive to runoff and therefore to soil loss. Thus implementation of improved miraba with mulching could be a very effective way to curb soil degradation by water erosion in the area. 


\subsection{Effectiveness of Selected Soil Conservation Practices in Relation to RUSLE Factors}

The relative effectiveness of selected soil conservation practices with reference to soil losses from cropl and with no SWC measures are presented in Fig. 5. It can clearly be seen that miraba sole, miraba with Tithonia and miraba with Tughutu mulching were more effective in reducing soil loss in Migambo than in Majulai village. This can be attributed to the differences in rainfall distribution where the poor rainfall distribution in Majulai village (Fig. 3) causes Napier grass in the miraba to die during dry spells, while the reliable rainfall in Migambo makes Napier grass barriers that form miraba to persist throughout the year and thus form denser grass strips than in Majulai village. It is evident from Fig. 4 that miraba reduced soil losses by about $80 \%$ in Majulai and $90 \%$ in Migambo village relative to soil losses from cropland with no SWC measures. On the other hand miraba with Tithonia and Miraba with Tughutu mulching reduced soil losses by $90 \%$ in Majulai and $95 \%$ in Migambo village relative to soil losses from cropl and with no SWC measures (Fig. 5).

Based on the work by Kabanza et al. [32] RUSLE factors were found to provide better insight than other attributes when assessing the effectiveness of soil conservation measures. The observed $K$ factors were $0.0016\left(\mathrm{Mg} \mathrm{h} \mathrm{MJ}^{-1} \mathrm{~mm}^{-1}\right)$ for Chromic Acrisol in Majulai and $0.0018\left(\mathrm{Mg} \mathrm{h} \mathrm{MJ}^{-1}\right.$ $\mathrm{mm}^{-1}$ ) for Haplic Acrisol in Migambo village (Table 4). The observed $K$ factor values are very low, indicating high susceptibility of the studied soils to erosion. More erodible soils such as silt loams have their $K$ factor values ranging from $0.03-0.05\left(\mathrm{Mg} \mathrm{h} \mathrm{MJ}^{-1} \mathrm{~mm}^{-1}\right)[37,38]$. The $P$ factor values are much higher in Majulai than in Migambo village (Table $3 \& 4$ ) indicating that the studied soil conservation practices have stronger effect in Migambo than in Majulai village. This can be explained by the good rainfall distribution in Migambo as compared to Majulai village which experiences long dry spells (Fig. 3) resulting natural death of miraba Napier grass, thus, reducing its effectiveness. Similarly significant differences were observed between soil conservation practices where miraba with Tithonia and miraba with Tughutu mulching were more effective in reducing soil loss than miraba sole and control (plots with maize or bean crop). This is due to the fact that grass barriers forming miraba and mulches tend to reduce runoff speed there by increasing the rate of infiltration. This tendency was also reported by Dur'an et al. [39], Reubens et al. [40], Wanyama et al. [34] and Birru et al. [41]. The most effective soil conservation practices in both villages are thus miraba with Tithonia and miraba with Tughutu mulching $(P=0.11$ for Majulai and $P=0.002$ for Migambo village).

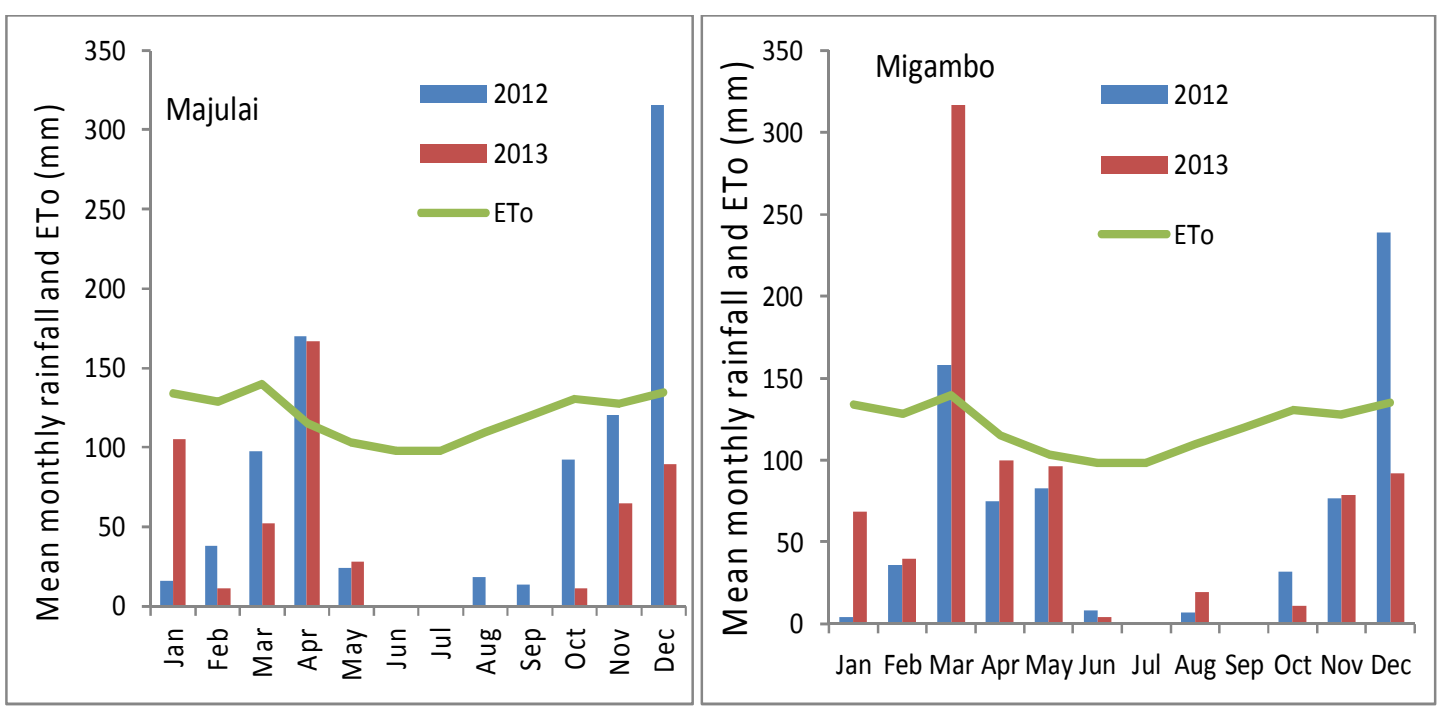

Fig. 3. Rainfall distribution in Majulai and Migambo villages and estimated reference evapotranspiration (ETo) measured during 2012 and 2013; ETo determined according to New_LocClim estimator; [19] 
Table 1. Rainfall and annual soil losses measured in Majulai and Migambo villages Lushoto District, Tanzania

\begin{tabular}{|c|c|c|c|c|c|c|}
\hline & & & \multicolumn{2}{|c|}{ Majulai } & \multicolumn{2}{|c|}{ Migambo } \\
\hline & & & 2012 & 2013 & 2012 & 2013 \\
\hline \multicolumn{7}{|l|}{ Rainfall (mm) } \\
\hline & Long rains (Feb.- May) & & 329.3 & 258.0 & 359.4 & 552.1 \\
\hline & $\begin{array}{l}\text { Offseason rains (Aug - } \\
\text { Sept.) }\end{array}$ & & 28.7 & 0 & 7.1 & 23.4 \\
\hline & Short rains (Oct. - Jan.) & & 636.9 & 165.1 & 415.8 & 222.7 \\
\hline & Annual & & 906 & 528 & 718 & 826 \\
\hline \multirow[t]{2}{*}{$R\left(\mathrm{MJ} \mathrm{mm} \mathrm{ha}{ }^{-1} \mathrm{~h}^{-1}\right.$ year $\left.^{-1}\right)$} & & & 7774 & 3857 & 5859 & 7247 \\
\hline & & & \multicolumn{2}{|c|}{ Majulai } & \multicolumn{2}{|c|}{ Migambo } \\
\hline \multirow[t]{24}{*}{ Soil loss Mg ha ${ }^{-1}$ year $^{-1}$} & & & 2012 & 2013 & 2012 & 2013 \\
\hline & Bare plots & Replicates & & & & \\
\hline & & 1 & 254.6 & 100.6 & 175.6 & 177.1 \\
\hline & & 2 & 262.7 & 107.9 & 182.0 & 188.3 \\
\hline & & 3 & 266.9 & 105.7 & 183.6 & 186.6 \\
\hline & & Mean & 261.4 & 104.7 & 180.4 & 184.0 \\
\hline & Plots with maize or beans & 1 & 179.6 & 72.9 & 124.1 & 133.3 \\
\hline & & 2 & 183.3 & 76.8 & 124.3 & 129.8 \\
\hline & & 3 & 187.8 & 77.2 & 124.4 & 131.6 \\
\hline & & Mean & 183.6 & 75.6 & 124.3 & 131.6 \\
\hline & Miraba with maize or beans & 1 & 34.7 & 12.2 & 13.3 & 14.9 \\
\hline & & 2 & 35.9 & 11.7 & 13.4 & 13.4 \\
\hline & & 3 & 33.6 & 14.3 & 13.5 & 14.3 \\
\hline & & Mean & 34.7 & 12.7 & 13.4 & 14.2 \\
\hline & $\begin{array}{l}\text { Miraba with Tithonia and } \\
\text { maize or beans }\end{array}$ & 1 & 17.58 & 5.42 & 8.02 & 5.30 \\
\hline & & 2 & 20.03 & 8.20 & 7.58 & 4.76 \\
\hline & & 3 & 20.05 & 9.09 & 7.97 & 5.18 \\
\hline & & Mean & 19.22 & 7.57 & 7.86 & 5.08 \\
\hline & $\begin{array}{l}\text { Miraba with Tughutu and } \\
\text { maize or beans }\end{array}$ & 1 & 18.47 & 5.62 & 7.97 & 5.47 \\
\hline & & 2 & 20.10 & 9.34 & 7.43 & 5.18 \\
\hline & & 3 & 20.02 & 9.33 & 7.24 & 5.27 \\
\hline & & Mean & 19.50 & 8.10 & 7.55 & 5.31 \\
\hline & $\operatorname{LSD}(P=.05)$ & & 4.14 & 4.06 & 4.14 & 4.06 \\
\hline & SE & & 1.39 & 1.37 & 1.39 & 1.37 \\
\hline
\end{tabular}

Table 2. Daily runoff $(\mathrm{mm})(\mathrm{Y})$ response to daily rainfall $(\mathrm{mm})(\mathrm{X})$ for Majulai and Migambo villages in Usambara Mountains, Tanzania

\begin{tabular}{llllll}
\hline Village/Treatments & $\begin{array}{l}\text { Regressions } \\
\text { equations }\end{array}$ & $\begin{array}{l}\text { Runoff } \\
\text { thresholds }\end{array}$ & $\mathbf{R}^{2}$ & $\begin{array}{l}\text { No. of rainfall } \\
\text { incidences }\end{array}$ & $\begin{array}{l}\text { No. of runoff } \\
\text { observations }\end{array}$ \\
\hline Majulai & & & & & \\
Bare plots & $\mathrm{Y}=0.230 \mathrm{X}-0.79$ & 3.4 & 0.87 & 118 & 353 \\
Control & $\mathrm{Y}=0.190 \mathrm{X}-0.72$ & 3.8 & 0.81 & 118 & 353 \\
Miraba & $\mathrm{Y}=0.065 \mathrm{X}-0.26$ & 4.0 & 0.66 & 118 & 353 \\
Miraba+Tithonia & $\mathrm{Y}=0.038 \mathrm{X}-0.15$ & 4.2 & 0.51 & 118 & 353 \\
Miraba+Tughutu & $\mathrm{Y}=0.037 \mathrm{X}-0.16$ & 4.2 & 0.52 & 118 & 353 \\
Migambo & & & & & \\
Bare plots & $\mathrm{Y}=0.200 \mathrm{X}-0.76$ & 3.8 & 0.93 & 122 & 365 \\
Control & $\mathrm{Y}=0.160 \mathrm{X}-0.68$ & 4.3 & 0.92 & 122 & 365 \\
Miraba & $\mathrm{Y}=0.040 \mathrm{X}-0.19$ & 4.7 & 0.81 & 122 & 365 \\
Miraba+Tithonia & $\mathrm{Y}=0.030 \mathrm{X}-0.13$ & 5.0 & 0.91 & 122 & 365 \\
Miraba+Tughutu & $\mathrm{Y}=0.027 \mathrm{X}-0.15$ & 4.9 & 0.89 & 122 & 365 \\
\hline
\end{tabular}



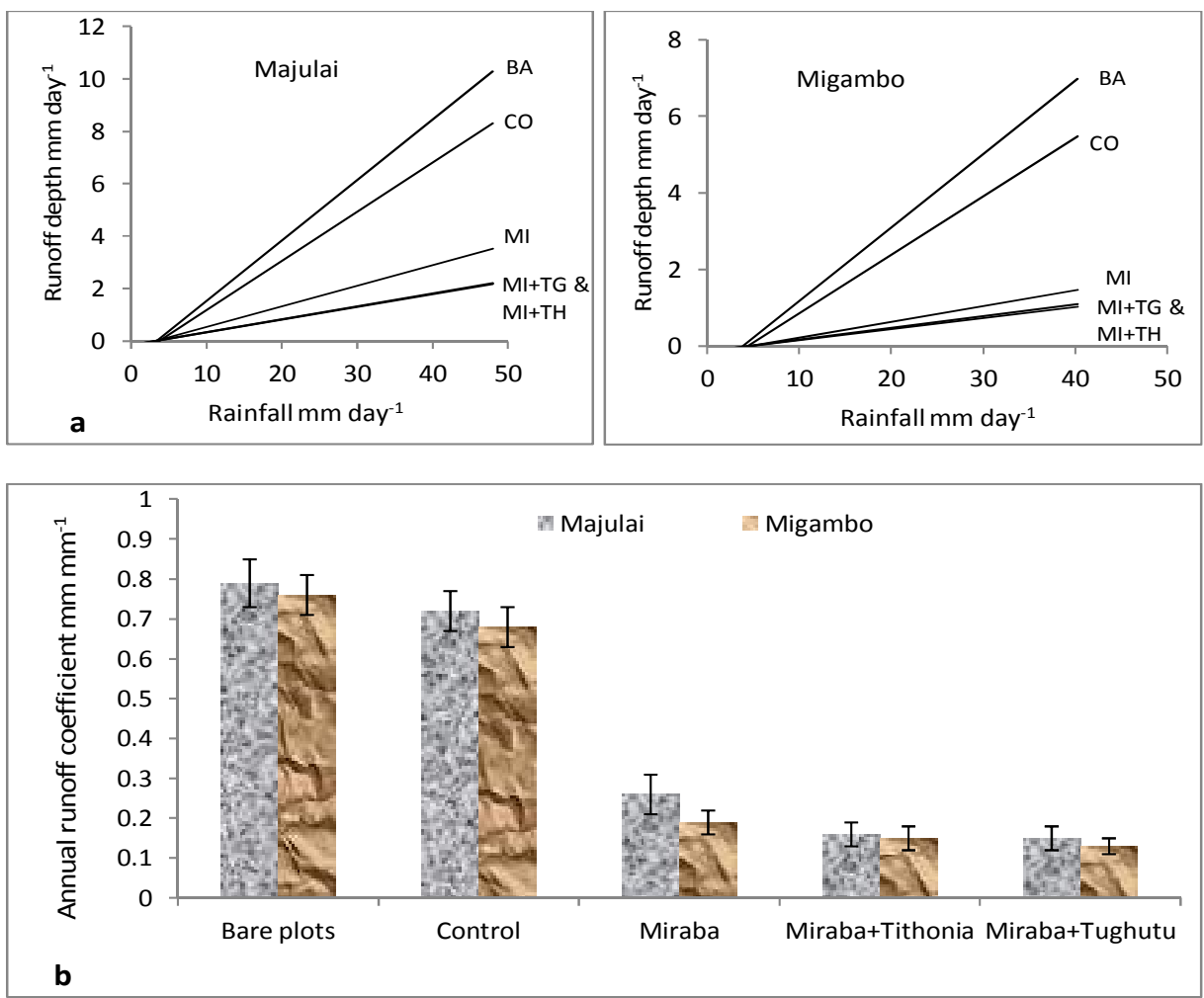

Fig. 4. a) Rainfall-runoff response curves b) runoff coefficients for different soil and water conservation measures in Usambara Mountains, Tanzania. (Key: BA= Bare plots; $C O=$ Control; $\mathrm{MI}=$ Miraba sole, $\mathrm{Ml}+\mathrm{TG}=$ Miraba with Tughutu mulching and MI+TH= Miraba with Tithonia mulching)

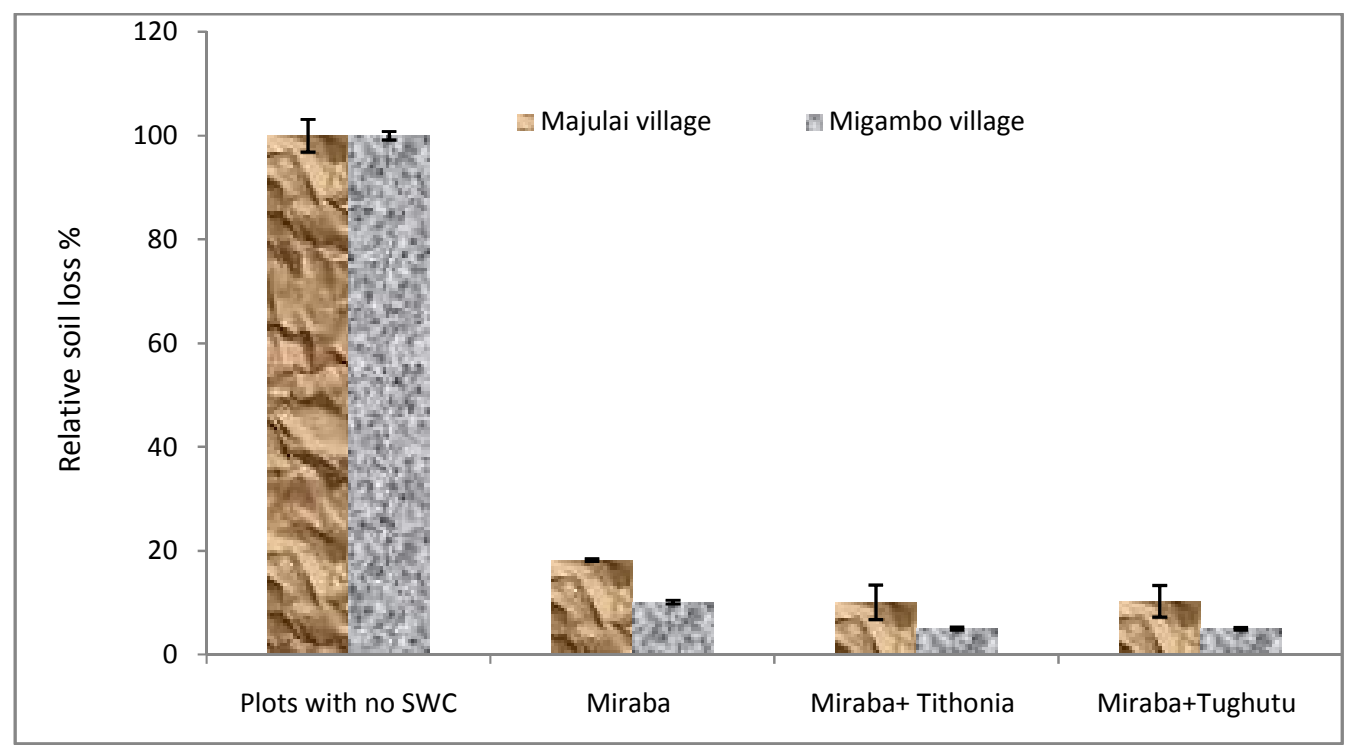

Fig. 5. The mean relative soil loss with STDEV from 3 replicates under the studied soil conservation practices in Majulai and Migambo villages 
Table 3. RUSLE factors for the Majulai and Migambo villages in Usambara Mountains, Tanzania based on soil loss measurements on runoff plots in 2012 and 2013

\begin{tabular}{llllllll}
\hline & \multicolumn{4}{c}{ Majulai } & \multicolumn{2}{c}{ Migambo } \\
\hline RUSLE factors & $\mathbf{n}$ & $\mathbf{2 0 1 2}$ & $\mathbf{2 0 1 3}$ & $\mathbf{2 0 1 2}$ & $\mathbf{2 0 1 3}$ & Sign. \\
\hline$R\left(\mathrm{MJ} \mathrm{mm} \mathrm{ha}^{-1} \mathrm{~h}^{-1}\right.$ year $\left.^{-1}\right)$ & & 1 & 7774 & 3857 & 5859 & 7247 & $\mathrm{~ns}$ \\
$K\left(\mathrm{Mg} \mathrm{h} \mathrm{MJ}^{-1} \mathrm{~mm}^{-1}\right)$ & 1 & 0.0018 & 0.0015 & 0.0020 & 0.0017 & $\mathrm{~ns}$ \\
$C$ (dimensionless) & Maize and beans & 3 & 0.71 & 0.70 & 0.70 & 0.70 & $\mathrm{~ns}$ \\
\hline$P$ (dimensionless) & & & & & & & \\
& Miraba & 3 & 0.19 & 0.17 & 0.10 & 0.10 & $* * *$ \\
& Miraba+Tithonia & 3 & 0.11 & 0.10 & 0.06 & 0.04 & $* * *$ \\
& Miraba+Tughutu & 3 & 0.11 & 0.10 & 0.06 & 0.04 & $* * *$ \\
& LSD $(P=.05)$ & & 0.03 & 0.03 & 0.03 & 0.03 & \\
\hline
\end{tabular}

LSD: least significant different; Sign.ns: not significant; ${ }^{\star * *}: P<.001$. Mann-Whitney $U$ test for $R, K$ and $C$ factors; Nested ANOVA for $P$ variables

Table 4. RUSLE factors for the Majulai and Migambo villages in Usambara Mountains, Tanzania based on soil loss measurements on runoff plots from 2012-2014 rain seasons

\begin{tabular}{|c|c|c|c|c|c|c|c|c|}
\hline & & \multicolumn{3}{|l|}{ Majulai } & \multicolumn{4}{|c|}{ Migambo } \\
\hline RUSLE factors & & Median & IQR & $\mathrm{n}$ & Median & IQR & $\mathrm{n}$ & Sign. \\
\hline$R\left(\mathrm{MJ} \mathrm{mm} \mathrm{ha}{ }^{-1} \mathrm{~h}^{-1} \mathrm{yr}^{-1}\right)$ & & 5816 & 1958 & 2 & 6553 & 694 & 2 & ns \\
\hline$K\left(\mathrm{Mg} \mathrm{h} \mathrm{MJ}^{-1} \mathrm{~mm}^{-1}\right)$ & & 0.0016 & 0.0002 & 2 & 0.0018 & 0.0002 & 2 & ns \\
\hline$C$ (dimensionless) & & Mean & STDEV & & Mean & STDEV & & \\
\hline Beans/weed/Maize & & 0.71 & 0.02 & 6 & 0.70 & 0.005 & 6 & ns \\
\hline \multirow[t]{5}{*}{$P$ (dimensionless) } & & Mean & STDEV & & Mean & STDEV & & \\
\hline & Miraba & 0.18 & 0.002 & 6 & 0.10 & 0.003 & 6 & $* * *$ \\
\hline & Miraba+Tithonia & 0.11 & 0.03 & 6 & 0.05 & 0.002 & 6 & $* * *$ \\
\hline & Miraba+Tughutu & 0.11 & 0.02 & 6 & 0.05 & 0.002 & 6 & $* * *$ \\
\hline & $\operatorname{LSD}(P=.05)$ & 0.03 & & & 0.03 & & & \\
\hline
\end{tabular}

LSD: least significant different; IQR: inter-quartile range; STDEV: standard deviation; $n$ : number of observations; Sign. $n s$ : not significant; ${ }^{* * *}: P<.001$. Friedman test for $R, K$ and $C$ factors; Nested ANOVA for $P$ variables

\subsection{Soil Nutrient Losses under the Studied SWC Measures}

Soil nutrient losses under soil conservation practices are presented in Fig. 6. Soil nutrient losses were significantly $(P<.001)$ different between SWC practices. The differences in soil nutrient losses can directly be associated with the effects of soil conservation practices (Table 5). Soil losses followed the trend: Bare plots > cropl and with no SWC measure (control) $>$ cropl and with miraba sole > miraba with Tughutu and miraba with Tithonia mulching (Table 5). Similarly Msita [16] in Migambo village, Tanzania reported lower losses of total $\mathrm{N}, \mathrm{P}$ and $\mathrm{K}^{+}$in plots with miraba, farmyard manure and Tithonia mulching than in cropl and with no SWC measures.

The relative effectiveness of soil conservation practices with reference to soil losses from cropland with no soil conservation measures are presented in Fig. 6. There are obvious differences in soil nutrient loss control between soil conservation measures. It is clear that miraba with mulching reduced soil nutrient losses by about $95 \%$ in Migambo and $85 \%$ in Majulai village, while miraba sole reduced nutrient losses by $90 \%$ in Migambo and about $80 \%$ in Majulai village (Fig. 6).

\subsection{Impact of Selected Soil Conservation Practices on Crop Productivity in the Two Studied Villages}

The yields of maize and beans are presented in Table 6. The results show that there is a significant $(P=.05)$ difference in crop yields between selected soil conservation practices and between the two studied years in both villages. In Majulai village maize grain yields were higher under miraba with Tughutu mulching than under miraba with Tithonia, miraba sole and control in 2012, but there was no maize yield in 2013 due to drought. The trend of bean grain yields followed the trend: miraba with Tughutu > miraba with Tithonia $>$ miraba sole $>$ control. The trend was similar in Migambo village where miraba with Tughutu > miraba with Tithonia > miraba sole $>$ control for both maize and bean grain yields (Table 6). Maize grain yields were 
significantly $(P=.05)$ higher in 2013 than in 2012 , but there were no significant $(P=.05)$ differencesv in bean grain yields between the two years of study except under miraba with Tithonia and miraba with Tughutu in Majulai village. There were also some differences in maize and bean yields between the two villages, with higher yields in Migambo than in Majulai (Table 6). The observed crop yields under the studied SWC practices (Table 6) were higher than the average yields according to FAO [42] of $1.5 \mathrm{Mg} \mathrm{ha}^{-1}$ for maize and of $0.7 \mathrm{Mg} \mathrm{ha}^{-1}$ for beans in Tanzania. It is clearly observed that the crop yield differences are highly influenced by the SWC practices (Table 6) and could partly be explained by differences in climatic conditions of the two villages. The rainfall in Majulai is unreliable while Migambo village experiences reliable rainfall with a fair distribution during the growing seasons (Fig. 3).
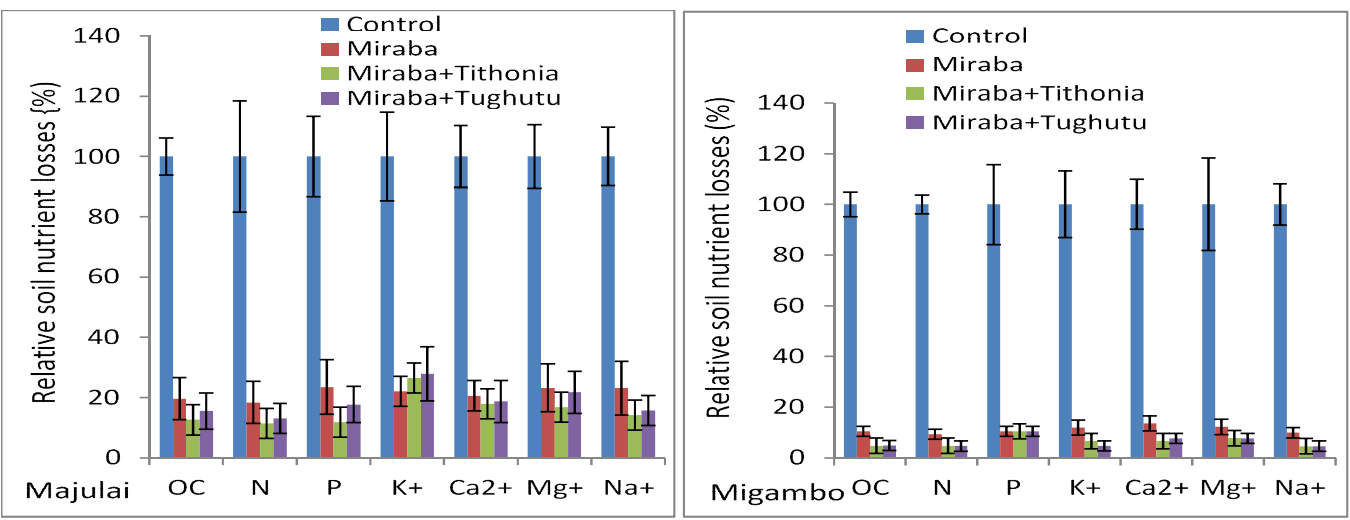

Fig. 6. The mean relative nutrient loss under the studied soil conservation practices in Majulai and Migambo village

Table 5. Soil nutrient loss $\left(\mathrm{kg} \mathrm{ha}^{-1}\right.$ year $\left.^{-1}\right)$ under the studied soil conservation practices in the two villages

\begin{tabular}{|c|c|c|c|c|c|c|c|c|c|}
\hline Village (year) & Treatments & $\mathbf{n}$ & OC & $\mathbf{N}$ & $\mathbf{P}$ & $\mathrm{K}^{+}$ & $\mathrm{Ca}^{2+}$ & $\mathrm{Mg}^{2+}$ & $\mathrm{Na}^{+}$ \\
\hline \multicolumn{10}{|l|}{ Majulai } \\
\hline & Bare & 72 & 4835.7 & 478.8 & 1.0 & 41.3 & 80.2 & 18.0 & 15.5 \\
\hline & Control & 72 & 3049.7 & 306.5 & 0.8 & 13.6 & 62.7 & 18.3 & 8.8 \\
\hline & Miraba & 72 & 632.7 & 59.2 & 0.2 & 2.7 & 12.8 & 4.0 & 2.3 \\
\hline & Miraba+Tithonia & 72 & 414.7 & 36.6 & 0.1 & 3.8 & 8.2 & 2.9 & 1.4 \\
\hline \multirow[t]{5}{*}{2012} & Miraba+Tughutu & 72 & 518.3 & 42.5 & 0.1 & 4.1 & 11.5 & 4.0 & 1.5 \\
\hline & Bare & 46 & 2024.3 & 176.3 & 0.7 & 5.9 & 23.9 & 8.4 & 6.5 \\
\hline & Control & 46 & 1496.7 & 125.7 & 0.9 & 6.8 & 25.9 & 8.4 & 4.6 \\
\hline & Miraba & 46 & 260.7 & 20.3 & 0.2 & 1.8 & 5.5 & 2.2 & 0.8 \\
\hline & Miraba+Tithonia & 46 & 158.7 & 12.6 & 0.1 & 1.6 & 7.7 & 1.6 & 0.5 \\
\hline \multirow{5}{*}{$\begin{array}{l}2013 \\
\text { Migambo }\end{array}$} & Miraba+Tughutu & 46 & 187.7 & 13.9 & 0.2 & 1.6 & 5.1 & 1.8 & 0.6 \\
\hline & Bare & 51 & 6092.3 & 548.0 & 0.8 & 12.0 & 371.1 & 57.2 & 11.3 \\
\hline & Control & 51 & 4908.7 & 474.3 & 0.7 & 19.7 & 262.1 & 46.3 & 8.8 \\
\hline & Miraba & 51 & 450.0 & 40.7 & 0.1 & 1.9 & 30.7 & 4.9 & 0.8 \\
\hline & Miraba+Tithonia & 51 & 251.7 & 27.2 & 0.1 & 1.7 & 20.3 & 4.5 & 0.5 \\
\hline \multirow[t]{5}{*}{2012} & Miraba+Tughutu & 51 & 276.7 & 26.0 & 0.1 & 1.2 & 20.2 & 4.3 & 0.5 \\
\hline & Bare & 71 & 6308.7 & 525.4 & 1.2 & 15.9 & 437.6 & 74.4 & 12.6 \\
\hline & Control & 71 & 4418.0 & 421.6 & 1.2 & 19.7 & 266.8 & 49.8 & 8.4 \\
\hline & Miraba & 71 & 531 & 43.8 & 0.1 & 2.8 & 41.1 & 6.8 & 0.9 \\
\hline & Miraba+Tithonia & 71 & 192.7 & 15.8 & 0.1 & 0.9 & 14.5 & 3.0 & 0.3 \\
\hline 2013 & Miraba+Tughutu & 71 & 183 & 16.4 & 0.1 & 0.7 & 15.4 & 3.1 & 0.3 \\
\hline
\end{tabular}


Table 6. Impact of selected soil conservation practices on crop yields in Majulai and Migambo villages

\begin{tabular}{|c|c|c|c|c|c|c|}
\hline \multirow[t]{2}{*}{ SWC measures } & \multirow[t]{2}{*}{$\mathbf{N}$} & \multicolumn{2}{|c|}{$\begin{array}{c}\text { Mean crop grain } \\
\text { Yields }\left(\mathrm{Mg} \mathrm{ha}^{-1}\right) \\
\text { in } 2012\end{array}$} & \multicolumn{2}{|c|}{$\begin{array}{l}\text { Mean crop grain } \\
\text { Yields }\left(\mathrm{Mg} \mathrm{ha}^{-1}\right) \\
\text { in } 2013\end{array}$} & \multirow[b]{2}{*}{$\operatorname{LSD}(P=.05)$} \\
\hline & & Maize & Beans & Maize & Beans & \\
\hline \multicolumn{7}{|l|}{ Majulai } \\
\hline Plots with no SWC & 3 & 0.71 & 0.59 & 0.0 & 0.59 & 0.15 \\
\hline Miraba sole & 3 & 1.26 & 0.81 & 0.0 & 0.85 & 0.15 \\
\hline Miraba with Tithonia & 3 & 1.62 & 0.89 & 0.0 & 1.04 & 0.15 \\
\hline Miraba with Tughutu & 3 & 1.97 & 0.93 & 0.0 & 1.09 & 0.15 \\
\hline $\operatorname{LSD}(P=.05)$ & & 0.15 & 0.15 & 0.0 & 0.15 & \\
\hline & \multicolumn{6}{|c|}{ Migambo } \\
\hline Plots with no SWC & 3 & 1.57 & 0.64 & 1.64 & 0.67 & 0.41 \\
\hline Miraba sole & 3 & 2.58 & 0.81 & 3.12 & 0.92 & 0.41 \\
\hline Miraba with Tithonia & 3 & 3.18 & 0.90 & 4.05 & 1.06 & 0.41 \\
\hline Miraba with Tughutu & 3 & 3.79 & 0.95 & 4.83 & 1.14 & 0.41 \\
\hline $\operatorname{LSD}(P=.05)$ & & 0.41 & 0.41 & 0.41 & 0.41 & \\
\hline SE & & 0.14 & 0.14 & 0.14 & 0.14 & \\
\hline \multicolumn{7}{|l|}{ Majulai * Migambo } \\
\hline $\operatorname{LSD}(P=.05)$ & & 0.32 & 0.32 & & 0.12 & \\
\hline SE & & 0.11 & 0.11 & & 0.04 & \\
\hline
\end{tabular}

LSD: least significant different; SE: standard error of means

In 2012, the average maize yields in Majulai village in creased by $177 \%$ under miraba with Tughutu, $128 \%$ under miraba with Tithonia and $78 \%$ under miraba sole while there were no maize yields in 2013 due to drought. Bean grain yields in 2012 and 2013 respectively increased by $58 \%$ and $85 \%$ under miraba with Tughutu, $51 \%$ and $76 \%$ under miraba with Tithonia and $37 \%$ and $44 \%$ under miraba sole when compared with control. In Migambo village during the same period the average maize yields increased by $149 \%$ and $195 \%$ under miraba with Tughutu, $109 \%$ and $147 \%$ under miraba with Tithonia and $70 \%$ and $90 \%$ under miraba sole when compared to control. Studies by Msita [15, 16] reported increased maize yields by $57 \%$ under miraba as compared to control in Migambo village, while bean yields did not differ and the maize yield differences were associated with improved soil properties due to the effects of miraba.

Bean grain yields in 2012 and 2013 respectively increased by $48 \%$ and $70 \%$ under miraba with Tughutu, $41 \%$ and $58 \%$ under miraba with Tithonia and $27 \%$ and $37 \%$ under miraba sole when compared with control. It is clear that soil conservation measures contribute to higher crop yields by reducing the loss of plant nutrients and assuring better water supply to the crop. The study by Wickama et al. [13] in Usambara
Mountains observed the average maize and bean yields of $270 \%$ and $583 \%$ higher in well managed farms with good quality terraces, well maintained grass strips, good quality seed for crops, adequate use of manure or fertilizer as compared to the control i.e. the farms with no terracing, no grass strips, use of local seed material, little use of manure and no use of fertilizer and no tree cover. The yield differences were reported to be influenced by the sustainable land management categories studied.

\section{CONCLUSIONS AND RECOMMENDATIONS}

Rainfall erosivity $R$ and soil erodibility $K$ factors did not differ significantly between the studied villages. Soil loss was significantly $(P=.05)$ higher under cropl and with no soil conservation measures (control) than under miraba with mulching. The $P$ factors were significantly $(P=$ .05 ) higher under miraba sole than under miraba with mulching. The annual nutrient losses were significantly $(P=.05)$ higher under control than under miraba with mulching. Maize and bean yields differed significantly $(P=.05)$ between soil conservation practices in the following order: miraba with Tughutu mulching >miraba with Tithonia mulching >miraba sole >control. Whereas miraba with either Tughutu or Tithonia mulching showed greater potential in reducing 
soil and nutrient losses than miraba sole, miraba with Tughutu mulching was more effective in improving crop yields than miraba with Tithonia and miraba sole. Despite that the soils of Usambara Mountains are susceptible to erosion, the $C$ and $P$ factors indicate that these soils are responsive to soil conservation measures. More local shrubs and grasses should be investigated for use as both green manure and soil conservation measure under miraba. Further research needs to be conducted to investigate effectiveness of the studied soil conservation practices on waters hed to mitigate river stream sedimentation. It is strongly recommended that Tithonia and Tughutu shrubs be planted in the borders of the farm plots along the slope for easy availability. It is also recommended in Majulai village that drought resistant grasses such Guatemala be used for establishing miraba since Napier grass which is mostly preferred for fodder is sensitive to drought.

\section{ACKNOWLEDGEMENTS}

The authors are grateful to the VLIR-UOS supported RIP-DSS SUA Project "Enhancing Indigenous Knowledge on Conservation Agriculture for Poverty Alleviation and Sustainable Livelihood, Usambara Mountains, Lushoto, Tanzania", for providing financial and logistical assistance to the research. The first author is grateful to the Tanzania Commission of Science and Technology (COSTECH) for sponsoring $\mathrm{PhD}$ programme that contributed to production of this paper.

\section{COMPETING INTERESTS}

Authors have declared that no competing interests exist.

\section{REFERENCES}

1. Faucette LB, Risse LM, Nearing MA, Gaskin JW, West LT. Runoff, erosion, and nutrient losses from compost and mulch blankets under simulated rainfall. Journal of Soil and Water Conservation. 2004;59:154- 160.

2. Descheemaerker K, Nyssen J, Poesen J, Raes D, Haile M, Muys B, Deckers S. Runoff on slopes with restoring vegetation: A case study from the Tigray Highlands, Ethiopia. Journal of Hydrology. 2006;331:219 - 241 .
3. Ajibade LT. Indigenous approach to the control of soil erosion among small scale farmers in Asa L.G.A. Kwara state, Nigeria. Ethiopian Journal of Environmental Studies and Management. 2008;1(1):1-6.

4. Kimaro DN, Poesen J, Msanya BM, Deckers J. Magnitude of soil erosion on the northern slope of the Uluguru Mountains, Tanzania: Interrill and rill erosion. Catena. 2008;75:38-44.

5. Jiao $P, X u$ D, Wang $S$, Wang $Y$, Liu $K$, Tang G. Nitrogen loss by surface runoff from different cropping systems. Soil Research. 2012;50:58-66.

Available:http://dx.doi.org/10.1071/SR1115 2.

6. $\mathrm{A} H \mathrm{I}$ (African Highlands Initiative). Annual report. District Agricultural Office Lushoto, Tanzania; 2001.

7. Tenge AJM. Participatory appraisal for farm-level soil and water conservation planning in West Usambara Highlands, Tanzania. Dissertation for Award of PhD Degree at Wageningen University, Netherlands. 2005;195.

8. Govers G, Poesen J. Assessment of the interrill and rill contributions to total soil loss from an upland field plot. Geomorphology. 1998; 1:343-354.

9. Msita HB, Kimaro DN, Deckers J, Poesen J. Identification and assessment of indigenous soil erosion control measures in the Usambara Mountains, Tanzania. In: 166 Earl T. Nardali (ed.), No Till Farming: Effect on soil, Pros and cons and potential. Nova Science Publishers, Hauppauge, NewYork. 2010;49-74.

10. Ellis-Jones J, Tengberg A. The impact of indigenous soil and water Conservation practices on soil productivity: Examples from Kenya, Tanzania and Uganda. Land Degradation and Development. 2000;11(1):19-36.

11. Vigiak O, Okoba BO, Sterk G, Stroosnijder L. Water erosion assessment using farmers' indicators in the Western Usambara Mountains, Tanzania. Catena. 2005;64(2-3):307-320.

12. Sheng TC. Bench terrace design made simple. Department of Earth Resources Colorado State University Fort Collins, CO 80523, USA. 2002;500 -504.

13. Wickama J, Okoba B, Sterk G. Effectiveness of sustainable land management measures in West Usambara 
highlands, Tanzania. Catena. 2014; 118:91-102.

14. Kyaruzi LA. Relationship between soil and land form derived land qualities and conservation agriculture practices in West Usambara Mountains, Tanzania. MSc Dissertation Sokoine University of Agriculture. 2013;140.

15. Msita HB, Kimaro DN, Mtakwa PW, Msanya BM, Dondeyne S, Poesen J, Deckers J. Effectiveness of miraba an indigenous soil and water conservation measures on reducing runoff and soil loss in arable land of western Usambara Mountains. Geophysical Research Abstracts. EGU2012-14122-2, 2012. EGU General Assembly. 2012;14.

16. Msita HB. Insights into indigenous soil and water conservation technologies in Western Usambara Mountains, Tanzania. $\mathrm{PhD}$ dissertation $\mathrm{KU}$ Leuven Belgium. 2013;198.

17. Renard KG, Foster GR, Weesies GA, McCool DK. Yoder DC. Predicting soil erosion by water: A guide to conservation planning with Revised Universal Soil Loss Equation (RUSLE), Agriculture, Handbook No. 703, USDA, ARS, Washington, DC; 1996.

18. Zarris D, Vlastara M, Panagoulia D. Sediment delivery assessment for a transboundary Mediterranean catchment: The example of Nestos River catchment. Water Resources 2011;25(14):3785-3803.

19. FAO (Food and Agriculture Organization). New_LocClim, Local climate estimator software, Agro meteorology group FAO/SDRN, Rome, Italy; 2006.

20. NATIONAL BUREAU OF STATISTICS. The 2012 population and housing census. Central statistical office of Tanzania, Dar es Salaam; 2012. (Accessed 09/08/2014). Available:http://www.nbs.go.tz/

21. FAO (Food and Agriculture Organization). World reference base for soil resources. A framework for International classification, correlation and communication. World Soil Resources Reports 106 FAO, Rome, Italy. $2014 ; 182$.

22. Kaswamila AL. Assessment of the Effectiveness of Soil Erosion Control Measures Using Soil Surface Micro topographic Features in the West Usambara Mountains, Tanzania. International Journal of Marine,
Atmospheric \& Earth Sciences. Florida, USA. 2013;2327-3356.

23. Shelukindo $\mathrm{H}$. Technical recommendations for soil and water conservation measures and agroforestry systems. SECAP and TIP, DALDO, Lushoto; 1995.

24. Wickama JM, Mowo JG. Indigenous nutrient resources in Tanzania. Managing African Soils. International Institute for Environment and Development, London. 2001;21:1560 -3520.

25. Ikerra ST. Use of minjingu phosphate rock combined with different organic inputs in improving phosphorus availability and maize yields on a chromic acrisol in Morogoro, Tanzania. PhD thesis Sokoine University of Agriculture, Morogoro, Tanzania. 2004;263.

26. Mowo JG, Janssen $\mathrm{BH}$, Oenema O, German LA, Mrema JP, Shemdoe RS. Soil fertility evaluation and management by smallholder farmer communities in Northern Tanzania. Agriculture, Ecosystems and Environment. 2006;116:47-59.

27. Yang J, Zhang G, Shi X, Wanga H, Cao Z, Ritsema CJ. Dynamic changes of nitrogen and phosphorus losses in ephemeral runoff processes by typical storm events in Sichuan Basin, Southwest China. Soil \& Tillage Research. 2009;105:292-299.

28. Moberg JP. Soil and plant analysis manual. The Royal Veterinary and Agricultural University, Chemistry Department, Copenhagen, Denmark. 2001;133.

29. Vrieling A, Sterk G, de Jong SM. Satellitebased estimation of rainfall erosivity for Africa. Journal of Hydrology. 2010;395:235-241.

30. Mitchell JK, Bubenzer GD. Soil loss estimation. In: Kirkby MJ, Morgan RPC,(eds): Soil erosion; John Wiley and Sons, Brisbane; 1980.

31. Genstat. Introduction to Genstat 14 for Windows. Statistical service centre, University of Reading, UK. 2011;41.

32. Kabanza AK, Dondeyne S, Kimaro DN, Kafiriti E, Poesen J, Deckers J. Effectiveness of soil conservation measures in two contrasting landscape units of South Eastern Tanzania. Zeitschrift für Geomorphologie. 2013;57(3):269-288. DOI: 10.1127/0372-8854/2013/0057-0102.

33. Liu $Y$, Tao $Y$, Wan KY, Zhang GS, Liu DB, Xiong GY, Chen F. Runoff and nutrient 
losses in citrus orchards on sloping land subjected to different surface mulching practices in the Danjiangkou Reservoir area of China. Agricultural Water Management. 2012;110:34-40.

34. Wanyama J, Herremans K, Maetens W, Isabirye M, Kahimba F, Kimaro D, Poesen J, Deckers J. Effectiveness of tropical grass species as sediment filters in the riparian zone of Lake Victoria. Soil Use and Management. 2012;28:409-418.

35. Bajracharya RM, Atreya K, Sharma S. Minimization of soil and nutrient losses in maize-based cropping systems in the midhills of central Nepal, Kathmandu, Nepal. 2005;1(1):1-10.

36. Tiwari KR, Sitaula BK, Bajracharya RM, Borresen T. Effects of soil and crop management practices on yields, income and nutrient losses from upland farming systems in the Middle Mountains region of Nepal. Nutrients Cycling Agroecosystems. 2010;86:241- 253.

37. Mtakwa PW, Lal R, Rsharma RB. An evaluation of the universal soil loss equation and field techniques for assessing soil erosion on a tropical Alfisol in Western Nigeria. Hydrological Processes. 1987;1(2):199-209.

38. Poesen J. Mechanisms of overland-flow generation and sediment production on loamy and sandy soils with and without rock fragments: Part I, in overland flow hydraulics and erosion mechanics, AJ. Parsons \& AD. Abrahams (eds.) UCL Press, London; 1992.

39. Dur'an Zuazo VH, Mart'ınez JRF, Pleguezuelo CRR, Mart'inez RA, Rodr'ıguez BC. Soil-erosion and runoff prevention by plant covers in a mountainous area (Spain): Implications for sustainable agriculture. Environmentalist. 2006;26:309-319.

40. Reubens B, Poesen J, Danjon F, Geudens $G$, Muys $B$. The role of fine and coarse roots in shallow slope stability and soil erosion control with a focus on root system architecture: A review. Trees. 2007; 21:385-402. DOI:10.1007/s00468-0070132-4.

41. Birru O, Quraishi S, Bedadi B. Effects of straw mulch and farm yard manure on runoff, erosion, in-situ water conservation, and yield and yield components of wheat at the highlands of Bale, South Eastern Ethiopia. African Journal of Agricultural Research. 2012;7(44):5879-5886.

42. FAO (Food and Agriculture Organization). Food and Agriculture Organization of the United Nation, 2010 FAOSTAT database, Production: Crops; 2010. (Accessed 16/01/2014). Available: http://faostat.fao.org/site/567/DesktopDefa ult.aspx

(c) 2015 Mwango et al.; This is an Open Access article distributed under the terms of the Creative Commons Attribution License (http://creativecommons.org/licenses/by/4.0), which permits unrestricted use, distribution, and reproduction in any medium, provided the original work is properly cited.

Peer-review history:

The peer review history for this paper can be accessed here: http://www.sciencedomain.org/review-history.php?iid=872\&id=37\&aid=7330 